
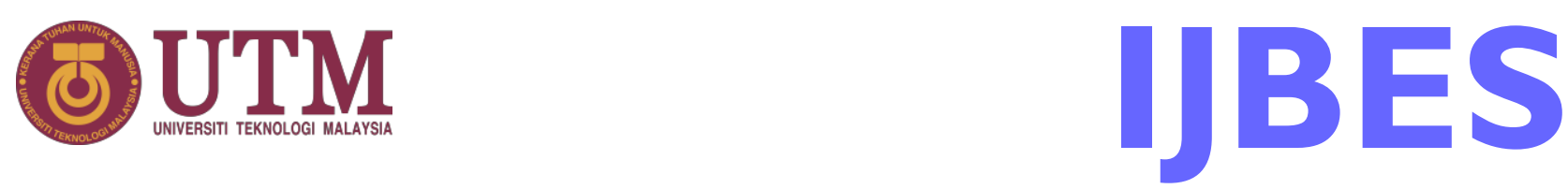

International Journal of Built Environment and Sustainability Published by Penerbit UTM Press, Universiti Teknologi Malaysia IJBES 8(2)/202I, II5-I26

\title{
Defining the Building Blocks and the Priority Areas for Cooperation Under the Belt and Road Initiative
}

\author{
Yaktor Joshua Inusa \\ Faculty of Built Environment and Surveying, Universiti Teknologi Malaysia, 81310 UTM Johor Bahru, Johor, Malaysia \\ Doris Hooi Chyee Toe \\ Faculty of Built Environment and Surveying, Universiti Teknologi Malaysia, 81310 UTM Johor Bahru, Johor, Malaysia
}

Kum Weng Yong

KW Yong Architect, 70300 Seremban, Negeri Sembilan, Malaysia

\begin{abstract}
The Belt and Road Initiative (BRI) is a China's endeavour to globally connect the countries along two major routes. This paper examines the keywords defining the building blocks and priority areas under the BRI and their relationship in order to foster a practical understanding of the BRI for enhancing regional cooperation and connectivity along the routes. The methodology employed was a systematic literature review involving four stages. Firstly, a broad search in the Scopus database (2016-2020) using BRI or similar terms returned $n=1,710$ articles which were further limited using the keywords: building blocks, priority areas, policy coordination, infrastructure connectivity, unimpeded trade, financial integration and people-to-people exchange. Other keywords considered were community and Silk Road. The articles were then screened and assessed resulting in 155 articles reviewed in this study. The review reveals that while the building blocks are the aim motivating the BRI, hence the spirit behind it, the five priority areas provide practical methods through which China and other countries along the Belt and Road routes will focus their collective development. The relationship between the two aspects owes to the fact that people are involved at all spheres of the initiative bringing about emphasis on the people-to-people exchange which is a core part of social dimension in sustainable development. In contribution, this paper presents a unique perspective for looking at the BRI for a focused discussion of its cooperative framework which could serve as a foundation for further research in various sectors.
\end{abstract}

\section{Article History}

Received: 19 July 2020

Received in revised form: 09 January 2021

Accepted: 04 February 2021

Published Online: 30 April 2021

\section{Keywords:}

Belt and Road Initiative, Green Development, Peace, Regional Cooperation and Connectivity, Shared Global Community, Silk Road

\section{Corresponding Author Contact:}

doristhchyee@utm.my

DOI: $10.11113 /$ ijbes.v8.n2.671

\section{Introduction}

As a global project, the Belt and Road Initiative (also known as One Belt One Road) is a China's brain child to connect the countries along two major routes - the "Silk Road Economic Belt" and the "21 $1^{\text {st }}$ Century Maritime Silk Road" (Amighini, 2017a; Huang, 2016; Lagutina, 2017; Mingjiang Li, 2015; Youfa Wang et al., 2017). This also came to promote the globalization and mutual inclusiveness which are lacking due to growing gaps in development and rising protectionist and nationalist stance (Kikuchi, 2018; Y. Li, 2017; W. Liu, 2016; Magri, 2017; Richet et al., 2017). It is a complete scheme for fostering socio-economic collaboration among countries along the Belt and Road region and it is beyond just constructing roads, railways and port facilities (W. Liu, 2016). Strategies similar to the Belt and Road Initiative can be perceived as a product of competitions between policy-makers on the local ground confronted by restrictions from home institutions and society and those in the global arena facing universal restrictions (Y. Li, 2017; 
Ngoei, 2018; Y. Qi et al., 2018).

As one of major cornerstones of the Belt and Road Initiative (BRI), the "Silk Road Economic Belt" (SREB) is a reaction to the long deliberated integration process in Eurasia via Russia and others among the largest republics in Central Asia, which eventually resulted in the Eurasian Economic Union (EEU) establishment in 2015 (Amighini, 2017b). The SREB has three routes: (1) Northwest China and Northeast China to Europe and the Baltic Sea through Central Asia and Russia; (2) Northwest China to the Persian Gulf and the Mediterranean Sea, passing through Central Asia and West
Asia; and (3) Southwest China through the Indochina Peninsula to the Indian Ocean (Office of the Leading Group for the Belt and Road Initiative, 2017). With a population of about 3 billion, the SREB contains a total area of 50 million square kilometers (Xu et al., 2017).

Meanwhile, the " $21^{\text {st }}$ Century Maritime Silk Road" (MSR) which is the second of the two key pillars (D. Chen and Yang, 2018) starts from (1) coastal ports of China crossing the South China Sea to the Indian Ocean, stretching to Africa and Europe; and (2) coastal ports of China via the South China Sea to the Pacific Ocean (Huang, 2016).

Table 1. Keywords defining the Belt and Road Initiative

\begin{tabular}{|c|c|c|}
\hline Keywords Category & Keyword & Source \\
\hline A. Outline & $\begin{array}{l}\text { 1. "Silk Road Economic Belt" } \\
\text { 2. " } 21^{\text {st }} \text { Century Maritime Silk Road" } \\
\text { 3. "Spirit of the Silk Road" } \\
\text { 4. "Silk Road Fund" } \\
\text { 5. "Asian Infrastructure Investment Bank" (AIIB) } \\
\text { 6. "Steering Group for BRI" } \\
\text { 7. "Vision and Actions" } \\
\text { 8. "Five-pronged approach" }\end{array}$ & $\begin{array}{l}\text { (Amighini, 2017a; CCTV, } \\
\text { 2017; Huang, 2016; } \\
\text { Lagutina, 2017; Mingjiang } \\
\text { Li, 2015; Na-Xi et al., } \\
\text { 2019; Ying Wang and } \\
\text { Chou, 2020; Youfa Wang et } \\
\text { al., 2017) }\end{array}$ \\
\hline B. Building Blocks & $\begin{array}{l}\text { 1. "Community of shared interests" } \\
\text { 2. "Community of shared responsibilities" } \\
\text { 3. "Community with a shared future" } \\
\text { 4. "Silk Road to green development" } \\
\text { 5. "Silk Road for health cooperation" } \\
\text { 6. "Silk Road to innovation" } \\
\text { 7. "Silk Road to peace" }\end{array}$ & $\begin{array}{l}\text { (CCTV, 2017; Dunford } \\
\text { and Liu, 2019; Khan et al., } \\
\text { 2018; Zeng, 2016) }\end{array}$ \\
\hline $\begin{array}{l}\text { C. Priority Areas for } \\
\text { Cooperation }\end{array}$ & $\begin{array}{l}\text { 1. "Policy coordination" } \\
\text { 2. "Infrastructure connectivity" } \\
\text { 3. "Unimpeded trade" } \\
\text { 4. "Financial integration" } \\
\text { 5. "People-to-people exchange" }\end{array}$ & $\begin{array}{l}\text { (CCTV, 2017; Dunford } \\
\text { and Liu, 2019; Huang, } \\
\text { 2016; Teo et al., 2019; } \\
\text { Valderrey et al., 2020; } \\
\text { Ying Wang and Chou, } \\
\text { 2020; Yin, 2019) }\end{array}$ \\
\hline D. Economic Corridors & $\begin{array}{l}\text { 1. "China-Mongolia-Russia Economic Corridor" (CMREC) } \\
\text { 2. "New Eurasian Land Bridge" (NELB) } \\
\text { 3. "China-Central Asia-West Asia Economic Corridor" } \\
\text { (CCWAEC) } \\
\text { 4. "China-Indochina Peninsula Economic Corridor" (CICPEC) } \\
\text { 5. "China-Pakistan Economic Corridor" (CPEC) } \\
\text { 6. "Bangladesh-China-India-Myanmar Economic Corridor" } \\
\text { (BCIMEC) }\end{array}$ & $\begin{array}{l}\text { (CCTV, 2017; Dunford } \\
\text { and Liu, 2019; Hussain, } \\
\text { 2017; Iqbal et al., 2019; } \\
\text { Jeganaathan, 2017; Menhas } \\
\text { et al., 2019; Pradhan, } \\
\text { 2018) }\end{array}$ \\
\hline E.Cooperation Mechanisms & $\begin{array}{l}\text { 1. "Shanghai Cooperation Organization" (SCO) } \\
\text { 2. "China-ASEAN (10+1) Cooperation" } \\
\text { 3. "Asia-Pacific Economic Cooperation" (APEC) } \\
\text { 4. "Asia-Europe Meeting" (ASEM) } \\
\text { 5. "Asia Cooperation Dialogue" (ACD) } \\
\text { 6. "Conference on Interaction and Confidence-Building Measures } \\
\text { in Asia" (CICA) } \\
\text { 7. "China-Arab States Cooperation Forum" (CASCF) } \\
\text { 8. "China-Gulf Cooperation Council (GCC) Strategic Dialogue" } \\
\text { 9. "Greater Mekong Subregion (GMS) Economic Cooperation" }\end{array}$ & $\begin{array}{l}\text { (Allison, 2018; CCTV, } \\
\text { 2017; Han et al., 2018; } \\
\text { Jeganaathan, 2017; Na-Xi } \\
\text { et al., 2019; Pepermans, } \\
\text { 2018; Svetlicinii, 2018; } \\
\text { Zeng, 2016) }\end{array}$ \\
\hline
\end{tabular}


10. "Central Asia Regional Economic Cooperation” (CAREC)

11. "Cooperation between China and Central and Eastern

European Countries" $(16+1)$

12. "Forum on China-Africa Cooperation" (FOCAC)

F. Projects Underway
1. "China-Belarus Industrial Park"
2. "Gwadar Port Free Zone"
3. "Colombo Port City"
4. "China Railway Express to Europe"
5. "Jakarta-Bandung railway"
6. "China-Laos railway"
7. "China-Thailand railway"
8. "Mombasa-Nairobi railway"
9. "Addis Ababa-Adama expressway"
10. "Karot hydropower project"

The Office of the Leading Group for the Belt and Road Initiative (2017) considers this decription as two main routes of the $21^{\text {st }}$ Century MSR. The $21^{\text {st }}$ Century MSR will pass the Eastern shores of the Arabian Peninsula across the Red Sea and the Suez Canal to the Mediterranean Sea (Fasulo and Talbot, 2017).

Seeing China's ambition of extending its reach globally through this initiative, it is important to ask; what are the building blocks, and the areas of focus of the BRI? And how are they related to foster the understanding of the BRI? Table 1 shows the keywords that describe the BRI. To some extend, these keywords give a comprehensive outlook of the intiative. These important keywords are grouped under six categories - outline, building blocks, priority areas for cooperation, economic corridors, cooperation mechanisms, and projects underway. Among these categories, the building blocks and the five priority areas for cooperation are fundamental to the understanding and implementation of the BRI as enshrined in NDRC (2015). So, it is important to focus on the "building blocks" and "priority areas" for cooperation to foster better understanding of the BRI. This paper seeks to examine the "building blocks" and the five "priority areas" for cooperation of the BRI and discuss their relationship.

\section{Methodology}

The methodology for this study employed a systematic literature review procedure as illustrated in Figure 1. This approach involved four stages. Firstly, a search was conducted using the broad topic and the Boolean operator as follows: "Belt and Road Initiative" OR BRI OR “One Belt One Road” OR OBOR from 2016 to 2020. This returned 1,710 (research, review, and conference) articles which were then further limited by keyword search within the result. These keywords employed were building blocks $(n=9)$, priority areas $(n=3)$, policy coordination $(n=20)$, infrastructure connectivity $(n=4)$, unimpeded trade $(n=12)$, financial integration $(n=18)$ and people-to-people exchange $(n=21)$.

Other keywords considered were community $(n=320)$ and Silk Road $(n=728)$ which were further narrowed by specific keyword search. These keywords returned results as follows: shared interests $(n=3)$, shared responsibilities $(n=1)$ and shared future $(n=24)$ within the term community, and green development $(n=12)$, health cooperation $(n=6)$, innovation $(n=145)$ and peace $(n=106)$ within the term Silk Road. Overall, the first stage returned a total of $n=384$ articles.

Secondly, the next stage involved removal of duplicates and subsequent screening of the articles. Having removed the duplicates, the number of articles included were $n=310$. Furthermore, these articles were screened based on the related titles. Also, articles outside the search limit were screened. Therefore, the number of articles included based on related title and those screened outside the search limits were $n=221$ and $n=27$ respectively; these were further assessed.

In the third stage, these articles were assessed and included based on their relevance and contribution to this study. The articles included after the assessment were $\mathrm{n}=134$ for those from Scopus database from 2016 to 2020 and $n=21$ for those outside the limit. Finally, the fourth stage involved the review of the articles. The total number of the articles reviewed were $n=155$ which distribution is presented in Figure 2; also, as shown in the figure, n=94 articles were cited. 


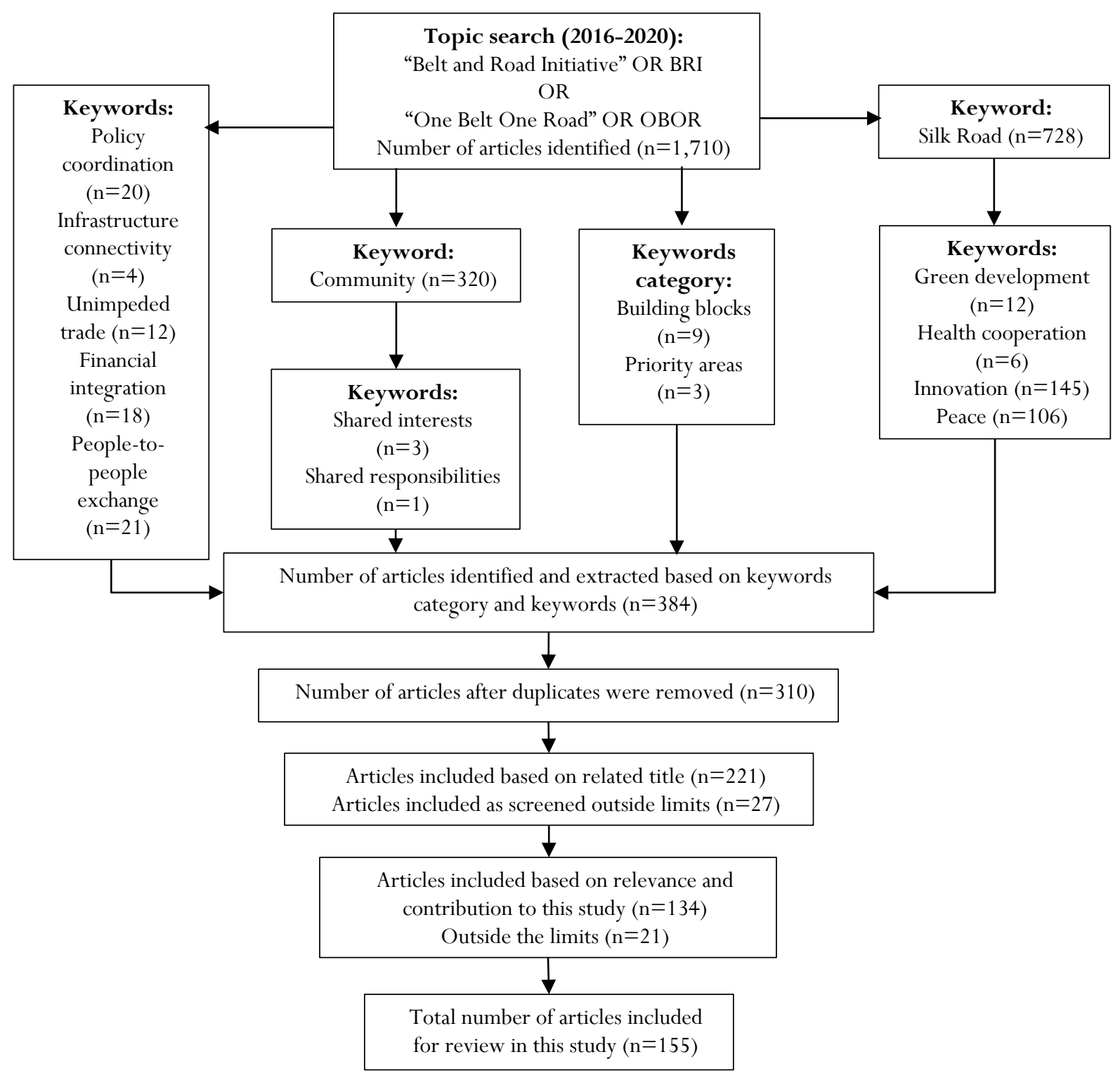

Figure 1.Stages of the review procedure

\section{The Building Blocks Of The Belt And Road Initiative}

The keywords that explain the building blocks of the BRI are as follows: "community of shared interests" (Dunford and Liu, 2019), "community of shared responsibilities", "community with a shared future” (Akçay and Qingye, 2020; Dong et al., 2018; Hu, 2019; Khan et al., 2018; A. Liu and Guan, 2017; Nordin and Weissmann, 2018; Xiangyang, 2019; Zeng, 2016; Y.-J. Zhang et al., 2020), Silk Road to green development, Silk Road to innovation, Silk Road to peace, and Silk Road for health cooperation (CCTV 2017).
Figure 3 shows the connection of the building blocks with the initiative. As seen in the figure, BRI aimed at developing a global community of shared interests, responsibilities, and with a common future along the Silk Road with the attributes of green development, innovation, peace, and health cooperation. This relationship is considered to be the spirit behind the BRI (NDRC, 2015). When successfully implemented, the BRI is expected to impact the Silk Road and its interconnected regions and subsequently improving the quality of the settlements (Dong et al., 2018; Dunford and Liu, 2019; Hu, 2019; Khan et al., 2018; Zeng, 2016) 


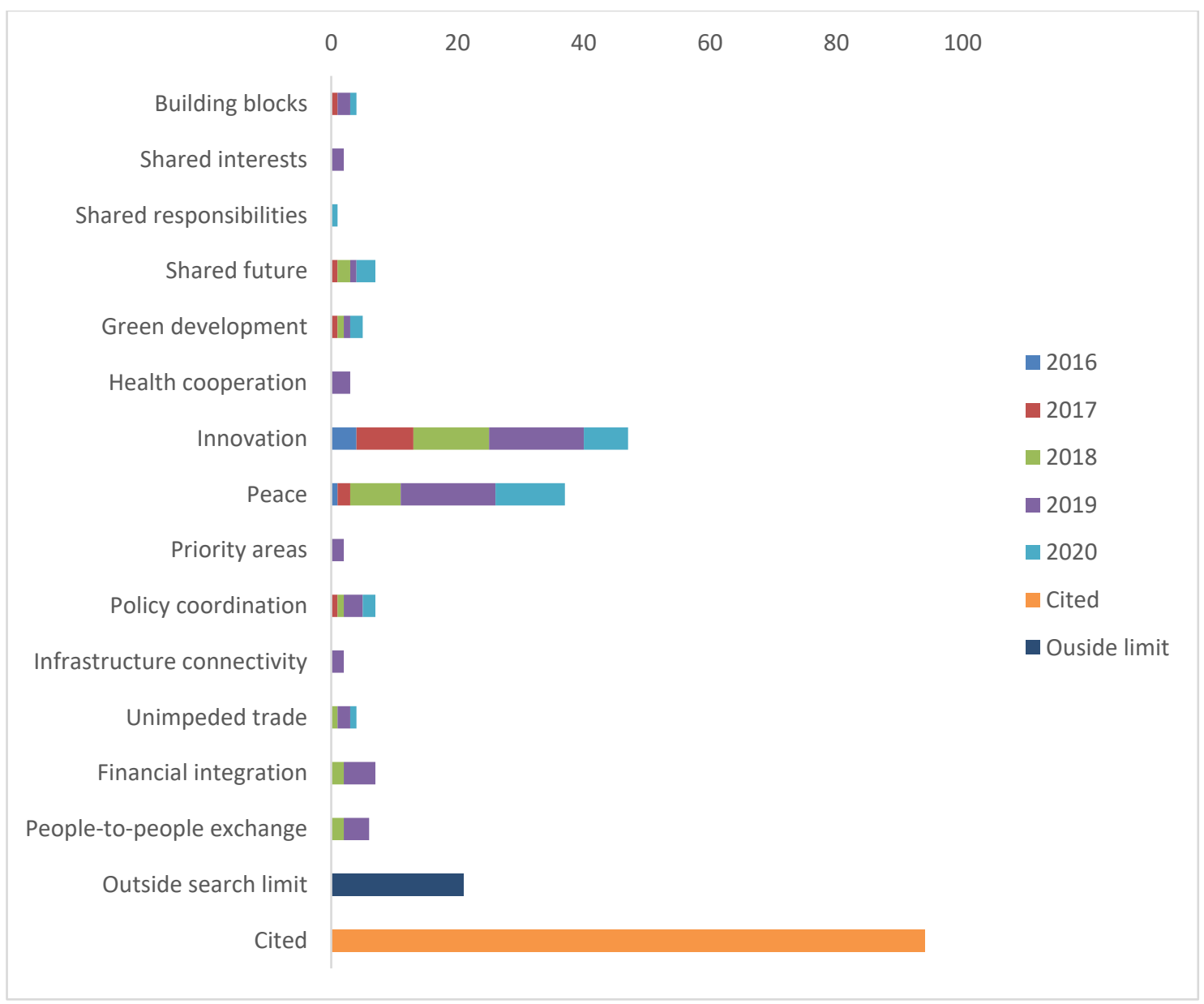

Figure 2. Distribution of articles reviewed and the number of cited articles in this study

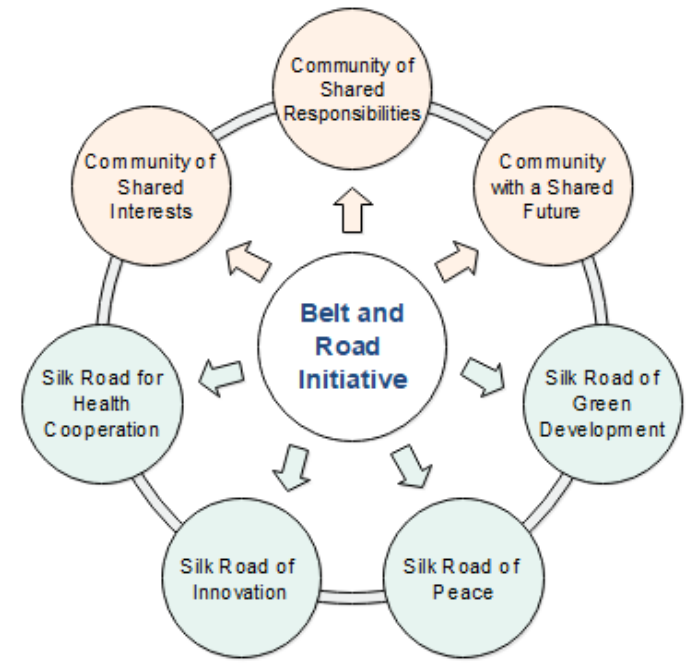

Figure 3. The building blocks of the Belt and Road Initiative

\subsection{Community: Shared Interests, Responsibilities And Future}

In terms of community, three building blocks are identified (Figure 3). Firstly, building a "community of shared interests" is one of the three targets of the BRI, which encourages joining hands to make a brighter future for all countries as the basic interests of mankind are necessary to each country (Liu, 2016; Office of the Leading Group for the Belt and Road Initiative, 2017; Khan et al., 2018). Through the development of a high-speed railway, the network of the coordinated channel and additionally the limit and efficiency of transport would be enhanced, in this way elevating China to frame a "community of shared interests" alongside different countries and regions (Shao et al., 2017). Furthermore, the reciprocal interdependence among the individuals with division of labour results into a "community of shared interests" because the individual's prosperity depends not only on the effort of each but on that of the participants collectively (Dunford and Liu, 2019).

Secondly, forming a "community of shared responsibilities" along with shared interests and common destiny (Zeng, 2016) highlight economic related coordination, socio-cultural extensiveness (A. Liu and Guan, 2017) and environmental control (W. Liu, 2016), which collectively make up the three pillars of sustainable development. 
The BRI is a gigantic project from China, aiming at encouraging a base for diversified cooperation and achieving win-win outcomes through shared responsibilities (Y. Li, 2017). Although some exceptions may occur, globalisation is about shared standards which are basic bits of the World Trade Organization (WTO) talks and assertions (Richet et al., 2017).

Finally, the initiative gives new impulse to the building of a community with a shared future for humankind (Dong et al., 2018; Lagutina, 2017). It exhibits a positive vision that the "Chinese Dream" is interconnected with the world dream and all countries cooperate to produce a human community of shared destiny (Khan et al., 2018; Nordin and Weissmann, 2018; Office of the Leading Group for the Belt and Road Initiative, 2017; Pendrakowska, 2018; Xiangyang, 2019) and to attain reciprocal benefits and win-win outcomes (Hu, 2019). Parties might cooperate to make a brighter future for all countries as the regular interests of mankind are crucial to each country and nation and rely upon the advancement of a global community of shared future (Jones, 2020; Office of the Leading Group for the Belt and Road Initiative, 2017). Two core connected components, shared development and shared future, form the basis for this joint globalisation (Khan et al., 2018). Likewise, a significant aspect of the Chinese model of building a community with a shared future for all people is global environmental cooperation (Dong et al., 2018). Energy collaboration is a crucial support and foundation for the BRI, and it is beneficial in promoting stable global energy market and the green energy revolution in BRI nations (Y.-J. Zhang et al., 2020).

\subsection{Silk Road: Green Development, Innovation, Peace And Health Cooperation}

In terms of Silk Road, four building blocks are recognized (Figure 3). Firstly, tightening involvement on ecological and environmental protection (Minjie Li et al., 2019; Teo et al., 2019), China is committed to building a green Silk Road (Jones, 2020; Office of the Leading Group for the Belt and Road Initiative, 2017). To Belt and Road cooperation practices, China "applies a green development philosophy" which shares its newest ideas, technologies, ecological restoration and progress, environmental protection, and pollution prevention and control, thereby actively fulfilling its responsibilities on crucial matters like sustainability and climate change (Dong et al., 2018; Office of the Leading Group for the Belt and Road Initiative, 2017; Suocheng et al., 2017; Xiheng, 2019). Suocheng et al. (2017) suggest that activities relating to tourism be organised particularly at the settlement (city, town or municipal) level as "green development" element. China, with National Agency for International Development Cooperation (NAIDC), is to additionally advance "green development under BRI and environmental diplomacy" (Dong et al., 2018, p. 6). For the unnecessary and mediocre investing nations, and to encourage the China's thermal power green development, pertinent economic, political and environmental hazard preventive and safety procedures should be reinforced (Yao et al., 2019).

Secondly, it is clear that China is the "world's second largest economy" with ability to move forward along the orbit of innovation (Lagutina, 2017). Professional mobility from home and diaspora can be effective vehicles for skills exchange, and for a sending nation, diaspora can be a vital source as well as a driver of research and innovation, technology exchange (Khan et al., 2018; Teo et al., 2019), and skills enhancement (Broadman, 2007; Z. Liu and Xin, 2019). In addition, a path to innovation entails deepened collaboration in frontline disciplines like the artificial intelligence, digital economy, nanotechnology, quantum computing, cloud computing, big data and smart cities (Dunford and Liu, 2019; Feng et al., 2019; Gui et al., 2019). Likewise, modernizing industries through innovation as well as spatial change, and searching new local and global markets are two main solutions to China's pursuit of newnormal period growth (W. Liu and Dunford, 2016; S.-Z. Qi et al., 2019; Saud et al., 2020). As the export market was hit after the beginning of the 2008-2012 global economic depression, joint policies were being implemented in line with innovation, and other similar development issues in China (Das, 2017; Durrani and Forbes, 2018; Jeganaathan, 2017). For example, "China already has an ambitious plan in its Industrial Masterplan 2025 [which] aimed at bringing at least 10 industries to world leadership" (Heiduk and Sakaki, 2019; Sheng, 2017). As a significant innovation in technology in the late $20^{\text {th }}$ century, the high-speed rail emergence has substantially decreased the travelling time among regions, suggesting considerable improvements at the transportation infrastructural level (F. Li et al., 2020). Innovation and globalisation encourage an inclination towards cooperative alliance and strategic connections among countries (Rauf et al., 2018; Z. Zhang et al., 2019). However, the long-standing economic development factors like innovation in science and technology as well as investment in staff training have been overlooked, and the long-standing economic development of participating nations is influenced (Sun et al., 2019; Wu et al., 2020).

Thirdly, maintaining closer economic ties, and deepening political acceptance; enhancing cultural bonds; encouraging civilizations to learn from one another and develop together; and promoting "mutual understanding, peace and friendship among people of all countries" are the official objectives of the BRI (S. I. Chan and Song, 2020; Cheng, 2016; Khan et al., 2018; Zeng, 2016). Cardinal to the aforementioned, the design of BRI is to foster "regional peace and prosperity" and inhibit conflict between bordering countries (Blah, 2018; Dunford and Liu, 2019; Farooq et al., 2019; Pepermans, 2018). For example, the government of China published its earliest "China's Arab Policy Paper" in January 2016; this appraised the development and demonstrated the driving principles of the SinoArab connection, while setting out a plan for win-win cooperation and restating "China's dedication to peace and stability in the Middle East" (J. Chen et al., 2018). Similarly, the BRI must endeavor to change the "Euro-Asia Great Game" from one that risks another major war to a sequence of gradual moves towards peace for more growth for the future generation (Sheng, 2017). Until now, China has avoided countries that are not peaceful and safe but with the exception of a few which it had earlier established strategic alliance before the BRI was established; Pakistan is one of these countries (Cheng, 2016; Heiduk and Sakaki, 2019).

Lastly, added to the BRI, China places premium to advancing participation among the related countries in the anticipation and 
control of infectious illnesses, restorative framework and approaches, healthcare education, staff training and interactions, and customary medicine (Office of the Leading Group for the Belt and Road Initiative, 2017; Youfa Wang et al., 2017). As the BRI has pursued developing a new center for health cooperation (branded the Healthy Silk Road), the justification to expand and strengthen connectivity globally will produce a substantial increase in people mobility which may heighten risk of spreading communicable diseases (Gostin, 2018; Gu and Qiu, 2019; J. Li et al., 2019; Murphy, 2018; Tang et al., 2017). Health cooperation among nations plays an essential role under the BRI (Qian et al., 2019). Health is a requisite requirement in promoting humanities in all development processes; it is an essential condition for socioeconomic development (J. Li et al., 2019).

\section{The Priority Areas For Cooperation Under The Belt And Road Initiative}

The priority areas for cooperation are five and they define the implementation methods of the BRI and at the same time give the BRI a focus (Ndzendze and Monyae, 2019). In NDRC (2015), countries along the Silk Road are encouraged to focus on these areas for their development and connectivity in line with the initiative ( $\mathrm{S}$. I. Chan and Song, 2020; Yinghui and Teng Teng, 2019).

Figure 4 shows the relationship of the five priority areas for cooperation and the BRI. Though the success of the initiative depends on the influence of the five priorities (Hughes et al., 2020; Jones, 2020), emphasis must be laid on the appropriate areas at a particular point in time according to contextual needs. When the priority areas are well articulated and implemented, they will impact the Belt and Road region, thereby exhibiting the success and quality of the BRI. By 2015, the implementation of the BRI had reached five years, "while the theoretical and empirical research on it is an emerging hot topic in current literature" (Y. Chen et al., 2019).

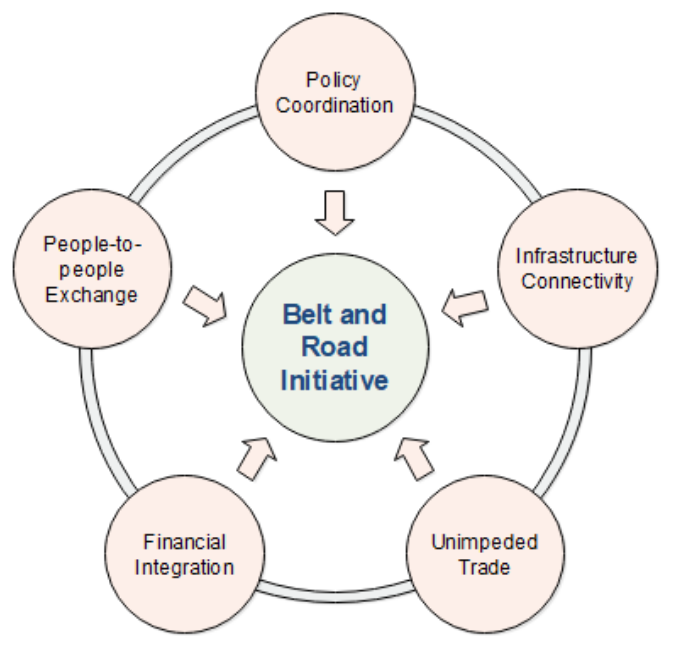

Figure 4. The five priority areas of the Belt and Road Initiative

\subsection{Policy Coordination}

Policy coordination among the countries in the Silk Road regions (Cheng, 2016) provides serious stability to the major economic endeavors (D. Chen and Yang, 2018). It is also an important factor in facilitating the harmonization of the implementation of issues regarding the other priority areas (Jones, 2020; Song, 2019; Sun et al., 2020). Policy coordination expects that nations along the "Belt and Road corridor" collectively create plans for development and measures to advance cross-border or regional cooperation through equitable consultation to resolve difficulties arising from cooperative undertakings (Valderrey et al., 2020; Ying Wang and Chou, 2020). Furthermore, policy coordination with capacity building under the BRI agenda can support certain BRI nations with fragile governance capacities improve their capabilities in managing environmental threats (Xiheng, 2019).

\subsection{Infrastructure Connectivity}

Infrastructure connectivity is a critical element of the BRI which is all-embracing in scope covering other areas (Huang, 2016; NDRC, 2015). The main focus of infrastructure connectivity are the "six means of communication” namely rail, highways, marine transport, aviation, pipelines, and aerospace integrated information network (Jones, 2020; Office of the Leading Group for the Belt and Road Initiative, 2017; Valderrey et al., 2020; Ying Wang and Chou, 2020). Infrastructure connectivity, being a "logistics-enabling factor", encompasses establishing an infrastructure web linking several sub-regions in Asia with other Asian parts, Africa and Europe (Ying Wang and Chou, 2020). Also, infrastructure connectivity is the fundamental guarantor for improving the sustainable development level in the Belt and Road region (Yin, 2019). Therefore, one can suggest that policymakers engaged in the BRI should focus on collectively developing smooth, efficient and secured transportation routes, linking main ports along the Belt and Road, while recognising that facilities construction for infrastructure connectivity can boost "logistics networks" (Valderrey et al., 2020; Ying Wang and Chou, 2020).

\subsection{Unimpeded Trade}

Trade facilitation, technical standards, improving customs regimes, and harmonization of regional trade agreements (Broadman, 2007) are main contributors for unimpeded trade (Yilmaz and Changming, 2019). Trade and investment cooperation is a "major task" in building the Belt and Road (Cheng, 2016), as well as driving force of the economy of the Silk Road countries (Wu et al., 2020). The institution of unimpeded trade along the Belt and Road is an important issue in the framework of aiding trade relationships; it was ranked the most important factor for logistics advancement under the BRI (Ying Wang and Chou, 2020). "Commissioning of new railway lines enhances trade facilitation in a more basic way" (Y. Li, 2017). Unimpeded trade is the keystone of the BRI and stands for trade liberalisation, trade barrier removal and free commerce promotion (Song, 2019; Taidong, 2019; Valderrey et al., 2020). Efforts to eradicate the trade environmental impact will be crucial to the enduring cooperation between China and nations along the Belt and Road while promoting unimpeded trade (Cuiyun and Chazhong, 
2020).

\subsection{Financial Integration}

Financial integration (Amighini, 2017b; D. Chen and Yang, 2018) serves as a cornerstone of the BRI (Cheng, 2016; Huang, 2016). The BRI will operate on a broad range of cross-border financial policy issues like currency convertibility and settlement, Asian bond market and China-ASEAN Banking Consortium. The initiative anticipates to enhance Asian monetary stability (Huang, 2016; Ying Wang and Chou, 2020). For instance, the Philippine Central Bank in October 2017 formally included the renminbi as to its international currency reserves thereby joining over $50 \%$ of BRI nations that have earlier adopted this approach (Rabena, 2018). Additionally, bilateral and multilateral cooperation financial system can be improved through finance institutions for regional development like the Asian Infrastructure Investment Bank (AIIB), the Silk Road Fund and the Brazil, Russia, India, China, and South Africa (BRICS) New Development Bank (Ying Wang and Chou, 2020). Financial integration, possibly, the most attractive BRI benefit is the prospective ease of obtaining finance from the funding institutions sustaining the initiative; member nations may be granted long-term loans under satisfactory situations for infrastructure and other project investments towards modernising facilities and improving the economy locally (Valderrey et al., 2020).

\subsection{People-To-People Exchange}

As the BRI aims to improve connectivity among Asia, Europe, and parts of Africa in the five priority areas, people-to-people exchange is crucial (Amighini, 2017b; NDRC, 2015). In providing public support, infrastructure and facilities, it naturally relates to the two aspects of interactions among the people and governments within the regions to facilitate policy coordination (Cheng, 2016). Crossborder tourism, disease control, joint research facilities for laboratories and political parties and parliamentary ties are also crucial means of facilitating mutual agreement and trust (Huang, 2016; Valderrey et al., 2020). The authorities of BRI stress the need to establish people-to-people exchange (Valderrey et al., 2020; Yuniarto, 2019). People-to people- exchange, for example, should take foreign communities or documented immigrants into cognisance as against the number of nations that a bearer of a particular passport may visit (Valderrey et al., 2020). In real situation, interaction is possibly the area with less outcomes to this day as many people are hesitant to accept immigrants in their countries, particularly because of cultural differences; also, there is a prevalent fear that immigrants may deny the locals jobs and opportunities (Valderrey et al., 2020).

\section{Discussion}

The questions in this research were "what are the building blocks, and the areas of focus of the BRI? And how are they related to foster the understanding of the BRI?" Having considered what the building blocks and the priority areas for cooperation of the BRI are, the question on how they are related to foster the understanding of the BRI is pertinent.
The aim of the BRI is to build a Silk Road community of shared interests, responsibilities and with a common future to exhibit the quality of green development, innovation, peace, and health cooperation. To achieve this, the BRI emphasises on focusing attention on the five priority areas for cooperation which can be considered as its implementation methods. Therefore, it can be hypothesised that when the five priority areas for cooperation are implemented appropriately, it will influence the BRI which will in turn affect the Silk Road regions as a global community to exhibit the qualities mentioned ealier.

These qualities are the indicators of the success of the BRI. Liu (2016) considers building a community of shared interests, responsibilities and with a shared future as "three targets," which presents economic incorporation and cultural abundance. The Office of the Leading Group for the Belt and Road Initiative (2017) has stressed the need for all Silk Road countries to forge a closer community of a shared future-oriented development model, sustain the open universal economy, and search for fresh sources for progress. For example, "in building the China-Mongolia-Russia Economic Corridor, China has been working vigorously to raise awareness of green development" (Office of the Leading Group for the Belt and Road Initiative 2017, p 37). The advent of global production operations has changed the world market into a place where there is very rapid innovation with striking decreases in product prices, rapid improvements in qualities, quick replacement of older product with new ones, and a premium on the rapid digital communication ability (Broadman, 2007). As social and political instability has profound economic bases, finding new enduring growth facilitators is exigent for a sustainable revival of the global economy and lasting peace (Y. Li, 2017). "Health indicators and social, economic, and environmental factors" (Wang et al. 2017) are cardinal to the success of the BRI.

As the initiative's aim is to strengthen infrastructure, achieve technical standardization and progressively form a facilities network to link the Silk Road regions in Asia, Europe and Africa (Huang, 2016), policy coordination is crucial for the successful implementation of the BRI. Removing barriers to facilitate investments is important to unimpeded trade. When financial cooperation and support are emphasized, economic growth is eminent (Huang, 2016). Policy coordination requires people's cooperation to succeed. Therefore, people-to-people exchange must be encouraged as it is one of the "two aspects of relationships among the people and governments within the regions" (Cheng, 2016) to make the initiative successful.

The building blocks forming the composition of the BRI are the communities and the routes. By way of analogy, just as a blue print contains the details of the components for constructing a building, the BRI is the "blue print" with specifications of the communities and routes as its building blocks for developing the Silk Road. As the components of the building are joined by different means depending on the part, so the communities and the routes which are the building blocks of the BRI could be joined by means of transportation and communication. For these to be realized, countries along the Silk Road have to focus on the five priority areas for cooperation under the BRI. Looking at this from the point of sustainable development, the relationship between the building blocks and the five priority 
areas (both within the confines of environmental and economic dimensions) can be seen in the involvement of people (social dimension) at all spheres of the initiative for various purposes.

The building blocks on the one hand include communities (inhabited by people) connected by routes through which people move and communicate. On the other hand, the five priority areas which include policy coordination, infrastructure connectivity, unimpeded trade and financial integration involve people's interactions as discussed earlier. Therefore, it is implied that people-to-people exchange of the five priority areas stands as an essential link between the building blocks and the priority areas. Furthermore, the significance of the people-to-people exchange has been demonstrated in a detailed and systematic content analysis of documentary videos (CCTV, 2016) comprising more than 200 episodes from 2016 to 2018. As part of a broader research along with this study, the detailed and systematic content analysis presents that although all of the five priority areas of the BRI were covered in the interviews with the locals, more than $80 \%$ of the documentary database focused on the core framework of peopleto-people exchange in all continents.

\section{Conclusions}

Having examined community of shared interests, responsibilities and with a shared future along the Silk Road to green development, innovation, peace and for health cooperation as building blocks of the BRI, this paper also considered the initiative's five priority areas which are policy coordination, infrastructure connectivity, unimpeded trade, financial integration and people-to-people exchange. While community and Silk Road as the building blocks remain the aim and likewise define the true spirit of the BRI, the five priority areas for cooperation are the implementation methods giving the BRI a focus for member countries to channel their resources in developing the region. Therefore, the building blocks and the five priority areas work together for the implementation of the BRI to bring about a win-win achievement, where emphasis is laid on making a green, peaceful and well-connected global community without deviation from the main agenda. The relationship between the two aspects owes to the fact that people are involved at all spheres of the initiative bringing about emphasis on the people-to-people exchange which is a core part of social dimension in sustainable development.

As a contribution, this paper explained the Belt and Road Initiative in a unique way from two main clusters of the keywords and their relationship in order to focus discussion on its cooperative framework which could serve as a basis for further research in various sectors. However, the extent to which the five priority areas are achieved is a subject of further research which could be done in the context of "projects underway". Also, the priority areas have potentials to drive the implementation of the BRI and require further research. This could be done by investigating the unique importance of people-to-people exchange to the BRI and its usefulness in modelling for the sustainable development of the Silk Road community.

\section{Acknowledgements}

This research is sponsored by a grant of the Research University Grant Scheme (No. Q.J130000.2521.19H13), Universiti Teknologi Malaysia. The authors also especially thank Dr. Kang Tong Hum and Railway Assets Corporation (RAC), Malaysia.

\section{References}

Akçay, N., and Qingye, T. (2020). Turkey's Perceptions of China's Belt and Road Initiative (2013-2017): Media and Think-Tanks Discourse Analysis. China Report, 56(2): 221-241. https://doi.org/10.1177/0009445520916877

Allison, R. (2018). Protective integration and security policy coordination: Comparing the SCO and CSTO. Chinese Journal of International Politics, 11(3): 297-338. https://doi.org/10.1093/CJIP/POY008

Amighini, A. (2017a). Policy Recommendations for the EU. In A. Amighini (Ed.), China's Belt and Road: a Game Changer? 141-144. Italian Institute for International Political Studies (ISPI).

Amighini, A. (2017b). Towards a New Geography of Trade? In A. Amighini (Ed.), China's Belt and Road: a Game Changer? 121-139. Italian Institute for International Political Studies (ISPI).

Blah, M. (2018). China's Belt and Road Initiative and India's Concerns. Strategic Analysis, 42(4): 313-332. https://doi.org/10.1080/09700161.2018.1482631

Broadman, H. G. (2007). Africa's Silk Road: China and India's New Economic Frontier. The World Bank.

CCTV. (2016). Homeland Dreamland, Episodes 1-303 [Video Files]. CCTV. https://www.youtube.com/playlist?list=PLfAyWdGHnLdF6krDKTJCdZ ONazB_Rcsxz

CCTV. (2017). Keywords to Understand China: the Belt and Road Initiative. China International Publishing Group and the China Academy of Translation.http: / / english.cctv.com/special/chinasbridgetotheworld//in dex.shtml

Chan, M. H. T. (2018). The Belt and Road Initiative - the New Silk Road: a research agenda. Journal of Contemporary East Asia Studies, 7(2): 104-123. https://doi.org/10.1080/24761028.2019.1580407

Chan, S. I., and Song, W. (2020). Telling the China story well: a discursive approach to the analysis of Chinese foreign policy in the "Belt and Road" Initiative. Chinese Political Science Review. 5: $417-$ 437.https://doi.org/10.1007/s41111-020-00146-1

Chen, D., and Yang, Z. (2018). Systematic optimization of port clusters along the Maritime Silk Road in the context of industry transfer and production capacity constraints. Transportation Research Part E: Logistics and Transportation Review, 109(2018): 174-189.

Chen, J., Shu, M., and Wen, S. (2018). Aligning China's Belt and Road Initiative with Saudi Arabia's 2030 Vision: Opportunities and Challenges. China Quarterly of International Strategic Studies, 04(03): 363-379. https://doi.org/10.1142/S2377740018500203

Chen, Y., Fan, Z., Zhang, J., and Mo, M. (2019). Does the Connectivity of the Belt and Road Initiative Contribute to the Economic Growth of the Belt and Road Countries? Emerging Markets Finance and Trade, 55(14): 3227-3240. https: / / doi.org/10.1080/1540496X.2019.1643315 
Cheng, L. K. (2016). Three questions on China's " Belt and Road Initiative ." China Economic Review, 40: 309-313.

Cuiyun, C., and Chazhong, G. (2020). Green development assessment for countries along the belt and road. Journal of Environmental Management, 263: 110344. https://doi.org/10.1016/j.jenvman.2020.110344

Das, K. C. (2017). The making of One Belt, One Road and dilemmas in South Asia. China Report, 53(2): 125-142.

Dong, L., Yang, X., and Li, H. (2018). The Belt and Road Initiative and the 2030 Agenda for Sustainable Development: seeking linkages for global environmental governance. Chinese Journal of Population Resources and Environment, 16(3):

203-210.

https://doi.org/10.1080/10042857.2018.1487745

Dunford, M., and Liu, W. (2019). Chinese perspectives on the Belt and Road Initiative. Cambridge Journal of Regions, Economy and Society, 12(1): 145-167. https://doi.org/10.1093/cjres/rsy032

Durrani, T. S., and Forbes, S. M. (2018). Entrepreneurship Along the New Silk Road: Business Challenges and Opportunities in the One Belt One Road Initiative. 2018 IEEE International Symposium on Innovation and Entrepreneurship (TEMS-ISIE), 1-6. https://doi.org/10.1109/TEMSISIE.2018.8478512

Farooq, M. S., Feroze, N., and Kai, Y. T. (2019). An Analysis of China and Africa Relations with Special Focus on 'One Belt and One Road.' India Quarterly: A Journal of International Affairs, 75(3): 366-379. https://doi.org/10.1177/0974928419860919

Fasulo, F., and Talbot, V. (2017). The MENA Region: Where the Belt Joins the Road. In A. Amighini (Ed.), China's Belt and Road: a Game Changer? (1st ed. 75-95). Italian Institute for International Political Studies (ISPI).

Feng, T., Kang, Q., Pan, B., and Yang, Y. (2019). Synergies of sustainable development goals between China and countries along the Belt and Road initiative. Current Opinion in Environmental Sustainability, 39: 167-186. https://doi.org/10.1016/j.cosust.2019.10.008

Garlick, J. (2017). If You Can't Beat 'em, Join 'em: Shaping India's Response to China's Belt and Road Gambit. China Report, 53(2): 143-157. https://doi.org/10.1177/0009445517696629

Gostin, L. O. (2018). China's “new” Silk Road: promise or peril for health, development, and human rights? British Medical Journal, 360: k816. https://doi.org/10.1136/bmj.k816

Gu, J., and Qiu, S. (2019). The Belt and Road Initiative and Africa's Sustainable Development: A Case Study of Kenya. IDS Bulletin, 50(4): 89 108. https://doi.org/10.19088/1968-2019.140

Gui, Q., Liu, C., and Du, D. (2019). The Structure and Dynamic of Scientific Collaboration Network among Countries along the Belt and Road. Sustainability, 11(19): 5187. https://doi.org/10.3390/su11195187

Han, L., Han, B., Shi, X., Su, B., Lv, X., and Lei, X. (2018). Energy efficiency convergence across countries in the context of China's Belt and Road Initiative. Applied Energy, 213: 112-122. https://doi.org/10.1016/j.apenergy.2018.01.030

Heiduk, F., and Sakaki, A. (2019). Introduction to the Special IssueChina's Belt and Road Initiative: the View from East Asia. East Asia, 36(2): 93-113. https://doi.org/10.1007/s12140-019-09312-y
Hu, B. (2019). Belt and Road Initiative: Five Years on Implementation and Reflection. Global Journal of Emerging Market Economies, 11(1-2): 1-10. https://doi.org/10.1177/0974910119871377

Huang, Y. (2016). Understanding China's Belt \& Road Initiative: Motivation, framework and assessment. China Economic Review, 40: 314 321.

Hughes, A. C., Lechner, A. M., Chitov, A., Horstmann, A., Hinsley, A., Tritto, A., Chariton, A., Li, B. V., Ganapin, D., Simonov, E., Morton, K., Toktomushev, K., Foggin, M., Tan-Mullins, M., Orr, M. C., Griffiths, R., Nash, R., Perkin, S., Glémet, R., Yu, D. W. (2020). Horizon Scan of the Belt and Road Initiative. Trends in Ecology \& Evolution. 35(7): 583-593. https://doi.org/10.1016/j.tree.2020.02.005

Hussain, E. (2017). China-Pakistan Economic Corridor: Will It Sustain Itself? Fudan Journal of the Humanities and Social Sciences, 10(2): 145-159. https://doi.org/10.1007/s40647-016-0143-x

Iqbal, B. A., Rahman, M. N., and Sami, S. (2019). Impact of Belt and Road Initiative on Asian Economies. Global Journal of Emerging Market Economies, 11(3): 260-277. https://doi.org/10.1177/0974910119887059

Jeganaathan, J. (2017). "OBOR” and South Asia: Can India and China cope with the emerging "new normal" in the region? Fudan Journal of the Humanities and Social Sciences, 10(2): 161-178.

Jones, L. (2020). Does China's Belt and Road Initiative Challenge the Liberal, Rules-Based Order? Fudan Journal of the Humanities and Social Sciences, 13(1): 113-133. https://doi.org/10.1007/s40647-019-00252-8

Khan, M., Sandano, I., Pratt, C., and Farid, T. (2018). China's Belt and Road Initiative: A Global Model for an Evolving Approach to Sustainable Regional Development. Sustainability, 10(11): 4234. https://doi.org/10.3390/su10114234

Kikuchi, T. (2018). Introduction: Trade, Industrialization, and Structural Reform in Southeast Asia. Journal of Asian Economics, 55: 1-3. https://doi.org/10.1016/j.asieco.2018.02.001

Lagutina, M. (2017). Improving Relations with Russia and Ukraine. In A. Amighini (Ed.), China's Belt and Road: a Game Changer? (1st ed. 53-74). Italian Institute for International Political Studies (ISPI).

Lechner, A. M., Chan, F. K. S., and Campos-Arceiz, A. (2018). Biodiversity conservation should be a core value of China's Belt and Road Initiative. Nature Ecology and Evolution. 2(3): 408-409 https://doi.org/10.1038/s41559-017-0452-8

Li, F., Su, Y., Xie, J., Zhu, W., and Wang, Y. (2020). The Impact of HighSpeed Rail Opening on City Economics along the Silk Road Economic Belt. Sustainability, 12(8): 3176. https://doi.org/10.3390/su12083176

Li, J., Xu, F., Sun, Z., and Wang, J. (2019). Regional differences and spatial patterns of health status of the member states in the "Belt and Road" Initiative. PLOS ONE, 14(1): $\quad$ e211264. https://doi.org/10.1371/journal.pone.0211264

Li, Mingjiang. (2015). China's “One Belt, One Road” Initiative: New Round of Opening Up? (RSIS Commentaries, No. 050). In RSIS Commentaries. Nanyang Technological University.

Li, Minjie, Wang, J., and Chen, Y. (2019). Evaluation and Influencing Factors of Sustainable Development Capability of Agriculture in Countries along the Belt and Road Route. Sustainability, 11(7): 2004. 
https: / /doi.org/10.3390/su11072004

Li, Y. (2017). Belt and Road: A Logic Behind the Myth. In A. Amighini (Ed.), China's Belt and Road: A Game Changer?. 13-33. Italian Institute for International Political Studies (ISPI).

Liu, A., and Guan, P. (2017). Big Data Technology Application under Belt and Road Initiative. 2017 Second Russia and Pacific Conference on Computer Technology and Applications (RPC): 11-13 https: / /doi.org/10.1109/RPC.2017.8168057

Liu, W. (2016). An Introduction to China's Belt and Road Initiative. Oxford International Infrastructure Consortium Global Infrastructure Conference [Slides Presentation].

Liu, W., and Dunford, M. (2016). Inclusive globalization: unpacking China's Belt and Road Initiative. Area Development and Policy. 1(3): 323340.https: / /doi.org/10.1080/23792949.2016.1232598

Liu, Z., and Xin, L. (2019). Has China's Belt and Road Initiative promoted its green total factor productivity ? __Evidence from primary provinces along the route. Energy Policy, 129: 360-369. https: / / doi.org/10.1016/j.enpol.2019.02.045

Magri, P. (2017). Introduction. In A. Amighini (Ed.), China's Belt and Road: A Game Changer? (1st ed. 7-12). Italian Institute for International Political Studies (ISPI).

Menhas, R., Mahmood, S., Tanchangya, P., Safdar, M. N., and Hussain, S. (2019). Sustainable Development under Belt and Road Initiative: A Case Study of China-Pakistan Economic Corridor's Socio-Economic Impact on $\begin{array}{lll}\text { Pakistan. } & \text { Sustainability, } & 6143 .\end{array}$ https: / / doi.org/10.3390/su11216143

Murphy, F. (2018). Rise of a new superpower: health and China's global trade ambitions. British Medical Journal, 360: k595. https: / /doi.org/10.1136/bmj.k595

Na-Xi, L., Meng-Fang, H., and Shan-Bing, L. (2019). How the Belt and Road Initiative Can Help Strengthen the Role of the SCO and Deepen China's Cooperation with Russia and the Countries of Central Asia. India Quarterly: A Journal of International Affairs, 75(1): 56-68. https: / / doi.org/10.1177/0974928418821484

NDRC. (2015). Vision and actions on jointly building Silk Road Economic Belt and 21st Century Maritime Silk Road. www.english.news.cn

Ndzendze, B., and Monyae, D. (2019). China's belt and road initiative: linkages with the African Union's Agenda 2063 in historical perspective. Transnational Corporations Review, 11(1): 38-49. https: / / doi.org/10.1080/19186444.2019.1578160

Ngoei, W.-Q. (2018). Doubling Down on Asia. Orbis, 62(1): 154-157.

Noel Dussort, M., and Marchetti, A. (2019). China's cooperation in Africa in the area of physical connectivity infrastructure. The case of the Mombasa-Nairobi railway line. JANUS NET E-Journal of International Relation, 2(10): 92-109. https: / / doi.org/10.26619/1647-7251.10.2.7

Nordin, A. H. M., and Weissmann, M. (2018). Will Trump make China great again? The belt and road initiative and international order. International Affairs. 94(2): 231-249. https://doi.org/10.1093/ia/iix242

Office of the Leading Group for the Belt and Road Initiative. (2017).
Building the Belt and Road: Concept, Practice and China's Contribution (1st ed., Issue May 2017). Foreign Languages Press.

Panthamit, N., and Chaiboonsri, C. (2020). China's Outward Foreign Direct Investment in the Greater Mekong Subregion. Journal of Economic Integration, 35(1): 129-151. https://doi.org/10.11130/jei.2020.35.1.129

Pendrakowska, P. (2018). Poland's perspective on the Belt and Road Initiative. Journal of Contemporary East Asia Studies, 7(2): 190-206. https: / / doi.org/10.1080/24761028.2018.1552491

Pepermans, A. (2018). China's 16+1 and Belt and Road Initiative in Central and Eastern Europe: economic and political influence at a cheap price. Journal of Contemporary Central and Eastern Europe, 26(2-3): 181-203. https: / /doi.org/10.1080/25739638.2018.1515862

Pradhan, R. (2018). The rise of China in Central Asia: the New Silk Road diplomacy. Fudan Journal of the Humanities and Social Sciences, 11(1): 9-29.

Qi, S.-Z., Peng, H.-R., and Zhang, Y.-J. (2019). Energy intensity convergence in Belt and Road Initiative (BRI) countries: What role does China-BRI trade play? Journal of Cleaner Production, 239: 118022. https: / /doi.org/10.1016/j.jclepro.2019.118022

Qi, Y., Dai, H., Geng, Y., and Xie, Y. (2018). Assessment of economic impacts of differentiated carbon reduction targets : A case study in Tianjin of China. Journal of Cleaner Production, 182: 1048-1059.

Qian, Y.-J., Ding, W., Wu, W.-P., Bandikhuu, A., Damdindorj, T., Nyamdorj, T., Bold, B., Dorjsuren, T., Sumiya, G., Guan, Y.-Y., Zhou, X.-N., Li, S.-Z., and Don Eliseo, L.-P. (2019). A path to cooperation between China and Mongolia towards the control of echinococcosis under the Belt and Road Initiative. Acta Tropica, 195: 62-67. https: / / doi.org/10.1016/j.actatropica.2019.04.022

Rabena, A. J. (2018). The Complex Interdependence of China's Belt and Road Initiative in the Philippines. Asia and the Pacific Policy Studies, 5(3): 683 697. https: / / doi.org/10.1002/app5.257

Rauf, A., Liu, X., Amin, W., Ozturk, I., Rehman, O., and Sarwar, S. (2018). Energy and Ecological Sustainability: Challenges and Panoramas in Belt and Road Initiative Countries. Sustainability, 10(8): 2743. https: / /doi.org/10.3390/su10082743

Richet, X., Ruet, J., and Wang, X. (2017). New Belts and Roads: Redrawing EU-China Relations. In A. Amighini (Ed.), China's Belt and Road: a Game Changer? (1st ed. 97-119). Italian Institute for International Political Studies (ISPI)

Rowedder, S. (2020). Railroading land-linked Laos: China's regional profits, Laos' domestic costs? Eurasian Geography and Economics, 61(2): 152 161. https: / /doi.org/10.1080/15387216.2019.1704813

Saud, S., Chen, S., Haseeb, A., and Sumayya. (2020). The role of financial development and globalization in the environment: Accounting ecological footprint indicators for selected one-belt-one-road initiative countries. Journal of Cleaner Production, 250: 119518. https: / /doi.org/10.1016/j.jclepro.2019.119518

Shao, Z., Ma, Z., Sheu, J., and Gao, H. O. (2017). Evaluation of large-scale transnational high-speed railway construction priority in the Belt and Road region. Transportation Research Part E 117: 40-57. https: / / doi.org/10.1016/j.tre.2017.07.007

Sheng, A. (2017). OBOR and EuroAsia's new great game. China Report, 
53(2): 232-252.

Song, G. (2019). China's economic strategy in Asia. Asian Education and Development Studies, 8(1): 2-13. https://doi.org/10.1108/AEDS-082017-0083

Sun, G., Yuan, C., Hafeez, M., Raza, S., Jie, L., and Liu, X. (2020). Does regional energy consumption disparities assist to control environmental degradation in OBOR: an entropy approach. Environmental Science and Pollution Research, 27(7): 7105-7119. https://doi.org/10.1007/s11356019-07360-8

Sun, Zhang, Xu, Yang, and Wang. (2019). Does the "Belt and Road Initiative" Promote the Economic Growth of Participating Countries? Sustainability, 11(19): 5240. https://doi.org/10.3390/su11195240

Suocheng, D., Kolosov, V., Yu, L., Zehong, L., Fujia, L., Minyan, Z., Guangyi, S., Huilu, Y., Hao, C., and Peng, G. (2017). Green Development Modes of the Belt and Road. Geography, Environment, Sustainability, 10(1): 53-69. https://doi.org/10.24057/2071-93882017-10-1-53-69

Svetlicinii, A. (2018). China's Belt And Road Initiative and the Eurasian Economic Union: "Integrating the Integrations." Public Administration Issues, 5: 7-20. https://doi.org/10.17323/1999-5431-2018-0-5-7-20

Taidong, Z. (2019). Aligning the Belt and Road Initiative with Myanmar's Sustainable Development Plan: Opportunities and Challenges. IDS Bulletin, 50(4): 69-88. https://doi.org/10.19088/1968-2019.139

Tang, K., Li, Z., Li, W., and Chen, L. (2017). China's Silk Road and global health. In The Lancet. 390 (10112): 2595-2601. https: / /doi.org/10.1016/S0140-6736(17)32898-2

Teo, H. C., Lechner, A. M., Walton, G. W., Chan, F. K. S., Cheshmehzangi, A., Tan-Mullins, M., Chan, H. K., Sternberg, T., and Campos-Arceiz, A. (2019). Environmental Impacts of Infrastructure Development under the Belt and Road Initiative. Environments, 6(6): 72 https://doi.org/10.3390/environments6060072

Valderrey, F. J., Montoya, M. A., and Sánchez, A. (2020). Latin America: The East Wing of the New Silk Road. Competition and Regulation in Network Industries, 21(1): 34 62. https://doi.org/10.1177/1783591719853537

Wang, Ying, and Chou, C.-C. (2020). Prioritizing China's public policy options in developing logistics infrastructure under the Belt and Road Initiative. Maritime Economics \& Logistics, 22(2): 293-307. https: / / doi.org/10.1057/s41278-019-00143-5

Wang, Youfa, Zhou, Z., Zhao, Y., Bai, R., Wang, X., Sun, X., Qu, W., Wang, Y., and Yan, H. (2017). Disparities in health burden, health-care facilities, and resources among countries in China's Belt and Road Initiative: a mixed methods study. The Lancet, 390: 85.

Wu, Z., Hou, G., and Xin, B. (2020). Has the Belt and Road Initiative Brought New Opportunities to Countries Along the Routes to Participate in Global Value Chains? SAGE Open, 1O(1): 215824402090208. https: / / doi.org/10.1177/2158244020902088

Xiangyang, L. (2019). The "Absence" of Asian Regional Economic Integration and the Development Orientation of the Belt and Road. Social $\begin{array}{lll}\text { Sciences } & \text { in } \quad \text { China, } & \text { 132-147. }\end{array}$ https: / /doi.org/10.1080/02529203.2019.1556484

Xiheng, J. (2019). Green Belt and Road Initiative Environmental and Social Standards: Will Chinese Companies Conform? IDS Bulletin, 50(4): 47-68. https: / /doi.org/10.19088/1968-2019.138

Xu, L., Fan, X., Wang, W., Xu, L., Duan, Y., and Shi, R. (2017). Renewable and sustainable energy of Xinjiang and development strategy of node areas in the "Silk Road Economic Belt." Renewable and Sustainable Energy Reviews, 79: 274-285.

Yao, R., Bai, H., and Xu, H. (2019). Where should China's thermal power industry prioritize its B\&R investment? A study based on an environmental site selection analysis. Journal of Cleaner Production, 215: 669-679. https: / /doi.org/10.1016/j.jclepro.2019.01.011

Yilmaz (Yao Shifan), S., and Changming, L. (2019). Remaking Eurasia: the Belt and Road Initiative and China-Russia strategic partnership. Asia Europe Journal. 18: 259-280 https://doi.org/10.1007/s10308-019-00547-1

Yin, W. (2019). Integrating Sustainable Development Goals into the Belt and Road Initiative: Would It Be a New Model for Green and Sustainable Investment? $\quad$ Sustainability, $\quad 11(24)$ : 6991. https://doi.org/10.3390/su11246991

Yinghui, W., and Teng Teng, Y. (2019). Repositioning Malaysian Chinese Educational Roles in Alignment with One Belt One Road Initiative. Círculo de Lingüística Aplicada a La Comunicación, 80: 287-302. https: / /doi.org/10.5209/clac.66613

Yuniarto, P. R. (2019). Intercultural Gaps Between Indonesia and China on the Belt and Road Initiative: Causes and Remedies. China Quarterly of International Strategic Studies, 05(03): 395-416. https: / / doi.org/10.1142/S2377740019500234

Zeng, L. (2016). Conceptual analysis of China's Belt and Road initiative: A Road towards a regional community of common destiny. Chinese Journal of International Law. 15(3): 517-541. https://doi.org/10.1093/chinesejil/jmw021

Zhang, Y.-J., Jin, Y.-L., and Shen, B. (2020). Measuring the Energy Saving and CO2 Emissions Reduction Potential Under China's Belt and Road Initiative. Computational Economics, 55(4): 1095-1116. https: / /doi.org/10.1007/s10614-018-9839-0

Zhang Z., Cheng J., Li T., and Wu Q. (2019) China Design Development Based on Trend-Driven Innovation Strategy Under the Belt and Road Initiative. In: Rebelo F., Soares M. (eds) Advances in Ergonomics in Design. AHFE 2018. Advances in Intelligent Systems and Computing, 777: 276-281. Springer, Cham. https://doi.org/10.1007/978-3-319-94706-8_31 